\title{
Direct rosiglitazone-induced modifications in insulin secretion, action and clearance: a single-dose hyperglycaemic clamp study
}

\author{
A. Farret $\cdot$ H. Chevassus $\cdot$ B. Roux $\cdot$ P. Petit $\cdot$ F. Galtier
}

Received: 21 February 2007 / Accepted: 19 March 2007 /Published online: 8 May 2007

(C) Springer-Verlag 2007

\begin{abstract}
Aims/hypothesis In addition to the improvement in insulin sensitivity, it has been shown that thiazolidinediones modulate beta cell function and insulin clearance in type 2 diabetic subjects. However, interactions between all these actions, and confounding factors due to co-morbidities and co-treatments in diabetic individuals, complicate the identification of specific effects. The aim of this pilot study was to investigate the potential acute effects of rosiglitazone on beta cell function and insulin sensitivity by the hyperglycaemic clamp technique in healthy volunteers.

Subjects and methods Twelve healthy men were included in a randomised, double-blind crossover study. Rosiglitazone $(8 \mathrm{mg})$ or placebo was given orally $45 \mathrm{~min}$ before the hyperglycaemic clamp ( $10 \mathrm{mmol} / \mathrm{l}$ for $2 \mathrm{~h}$ ).

Results The second phase of the insulin response was significantly decreased by rosiglitazone: $13,066 \pm 1,531$ vs $16,316 \pm 2,813 \mathrm{pmol} \mathrm{l}^{-1} 110 \mathrm{~min}$ in controls $(p<0.05)$, without change in the first phase. Serum C-peptide was not modified.
\end{abstract}

A. Farret $\cdot$ H. Chevassus $\cdot$ B. Roux $\cdot$ F. Galtier

CHU Montpellier, Centre d'Investigation Clinique,

Montpellier, France

A. Farret $\cdot$ H. Chevassus $\cdot$ B. Roux $\cdot$ F. Galtier

INSERM, CIC 0001,

Montpellier, France

P. Petit

Université Montpellier I, CNRS UMR 5232,

Montpellier, France

F. Galtier $(\bowtie)$

Centre d'Investigation Clinique, Hôpital St Eloi,

80 Avenue Augustin Fliche,

34295 Montpellier Cedex 05, France

e-mail: f-galtier@chu-montpellier.fr
Rosiglitazone treatment significantly increased insulin clearance (molar ratio of the C-peptide to insulin AUCs: $12.80 \pm$ 1.34 vs $11.38 \pm .33, p<0.05$ ) and the insulin sensitivity index (12.0 1.5 vs $\left.8.5 \pm 1.1 \mu \mathrm{mol} \mathrm{m}{ }^{-2} \min ^{-1} \mathrm{pmol}^{-1} 1, p<0.01\right)$.

Conclusions/interpretation The present results show that a single dose of rosiglitazone rapidly increases insulin clearance and insulin sensitivity index in healthy volunteers, with no direct effect on insulin secretion. The precise mechanisms mediating these actions remain to be determined. ClinicalTrials.gov ID no.: NCT00285142

Keywords C-Peptide $\cdot$ Diabetes $\cdot$ Healthy volunteers . Hyperglycaemic clamp · Insulin clearance · Insulin secretion · Insulin sensitivity · Rosiglitazone ·

Thiazolidinediones

\section{Abbreviations}

PPAR peroxisome proliferator-activated receptor

\section{Introduction}

Thiazolidinediones are high-affinity peroxisome proliferatoractivated receptor (PPAR)- $\gamma$ ligands [1]. In addition to their effect on insulin sensitivity, animal studies and long-term clinical studies have reported thiazolidinedione-induced modifications of beta cell function. This action can be either direct, or secondary to the improvement of insulin sensitivity. More recently, rosiglitazone was shown to increase insulin clearance in type 2 diabetic subjects after 12 weeks [2] and 16 weeks [3] of treatment. Although incompletely understood, this effect was considered to be secondary to a decreased liver fat content [3]. 
In an integrated system such as the human body, and after repeated administration, interactions between all these actions hamper the precise identification of specific effects. To differentiate between direct and secondary effects, evaluating immediate pharmacological actions after a single-dose administration can be helpful. To date, there are no data concerning acute effects of thiazolidinediones in humans. In addition, most evaluations were conducted in diabetic subjects in whom the underlying pathology, possible co-morbidities and co-treatments lead to various confusing factors. Healthy volunteers are a robust model allowing the investigation of pharmacological effects in humans with as few confounding factors as possible. Therefore, the aim of this pilot study was to investigate the potential acute effects of rosiglitazone on beta cell function and insulin sensitivity by the hyperglycaemic clamp technique in healthy volunteers.

\section{Subjects and methods}

The protocol, approved by the local ethics committee, was conducted in accordance with the Declaration of Helsinki as revised in 2000 and the Guideline for Good Clinical Practice (ICH Topic E6, 1996).

Subjects Twelve healthy Europid men, aged $26.5 \pm 1.5$ years, with normal $\left(21.7 \pm 0.4 \mathrm{~kg} / \mathrm{m}^{2}\right)$ and stable BMI, normal glycaemia $(4.7 \pm 0.1 \mathrm{mmol} / \mathrm{l})$ and insulinaemia $(31.2 \pm$ $4.6 \mathrm{pmol} / \mathrm{l})$ were included in this study after informed consent.

Study design This was a single-centre, randomised, doubleblind, placebo-controlled crossover study. Participants attended the research centre twice, once for the placebo session and once for the rosiglitazone session, conducted in random order, separated by a 6 week washout period.

Investigations At 07.00 hours, after an overnight fast at the study centre, a venous catheter was inserted into each forearm, one for administration of $30 \%$ dextrose $(1.67 \mathrm{~mol} / \mathrm{l})$, the other for blood sampling. Rosiglitazone $(8 \mathrm{mg}$ ) or placebo was administered orally $45 \mathrm{~min}$ before the onset of the dextrose infusion. Blood glucose was clamped at $10 \mathrm{mmol} / \mathrm{l}$ for 120 min according to DeFronzo et al. [4]. Briefly, participants received a priming dose based on their surface area and initial blood glucose. Continuous dextrose infusion was started $15 \mathrm{~min}$ later at a rate adjusted every $5 \mathrm{~min}$ on the basis of the prevailing plasma glucose concentrations.

Plasma samples for glucose were taken at $-50,-45,-30$, -15 and $0 \mathrm{~min}$, then every $5 \mathrm{~min}$ after starting the glucose infusion. After centrifugation $(6,700 \mathrm{~g}, 1 \mathrm{~min})$, glucose was immediately analysed (Glucose Analyser 2300 Stat Plus;
System Industry, Bourg St Andeol, France) and plasma was frozen at $-20^{\circ} \mathrm{C}$ for later laboratory glycaemia confirmation.

Samples were taken at $-50,-45,-30,-15,0,2.5,5,7.5$, $10,15,20,30,40,50,60,70,80,90,100$ and $120 \mathrm{~min}$ for serum insulin and C-peptide and at $-45,-30,-15,0,15$, $20,30,45,60,90$ and $120 \mathrm{~min}$ for plasma rosiglitazone. After centrifugation at $2,500 \mathrm{~g}$, serum and plasma were immediately frozen at $-20^{\circ} \mathrm{C}$.

Immediately after discontinuation of the glucose infusion, urine was collected to determine urinary glucose excretion.

Biochemical analysis Serum insulin and C-peptide were measured by RIA (BI-INSULIN IRMA and IRMA-C-PEP; CIS Bio-international, Gif-sur-Yvette, France). Plasma glucose was assayed by the glucose oxidase method; rosiglitazone concentrations were assayed by HPLC and tandem mass spectrometric detection (LC-MS/MS; Pharma Bio-Research Group BV, Zuidlaren, the Netherlands).

Calculated indexes First and second phases of insulin and C-peptide responses were the AUCs of their concentrations from 0 to $10 \mathrm{~min}$ and 10 to $120 \mathrm{~min}$, respectively. The insulin sensitivity index was the mean glucose infusion rate divided by the mean plasma insulin concentration from 60 to $120 \mathrm{~min}$, after correcting for urinary glucose excretion [4]. AUCs were determined by the trapezoidal rule.

Fasting glucose and insulin levels were the average of two baseline samples. Insulin clearance was assessed as the molar ratio of the C-peptide to insulin AUCs [5] for each phase of the insulin response and for the total duration of the clamp.

Statistical analysis Results are expressed as means \pm SE. Comparisons of means were performed by repeatedmeasures ANOVA with assessment of carry-over effect, after $\log _{\mathrm{e}}$ transformation for non-parametric variables. Pearson correlations after logarithmic transformation and Spearman correlations were used when appropriate. Systat 10.0 software for Windows from SPSS (Chicago, IL, USA) was used for statistical analysis. The level of significance was set at $p<0.05$.

\section{Results}

Mean baseline glycaemia was similar between the treatment and the placebo sessions $(5.4 \pm 0.1$ vs $5.3 \pm 0.1 \mathrm{mmol} / \mathrm{l}$, respectively, NS). During the hyperglycaemic clamp, mean glycaemia was identical for the two sessions (10.2 \pm $0.1 \mathrm{mmol} / 1$, Fig. 1a). Plasma rosiglitazone concentrations peaked at $875.5 \pm 203.1 \mathrm{nmol} / \mathrm{l}(415 \pm 96 \mu \mathrm{g} / \mathrm{l})$ at $0 \mathrm{~min}$, then 
Fig. 1 Mean glucose (a), rosiglitazone (b), insulin (c) and Cpeptide (d) concentrations after treatment administration and during the hyperglycaemic clamp: closed circles, rosiglitazone session; open circles, placebo session; to convert rosiglitazone levels from nmol/ 1 to $\mu \mathrm{g} / 1$, multiply by 0.474
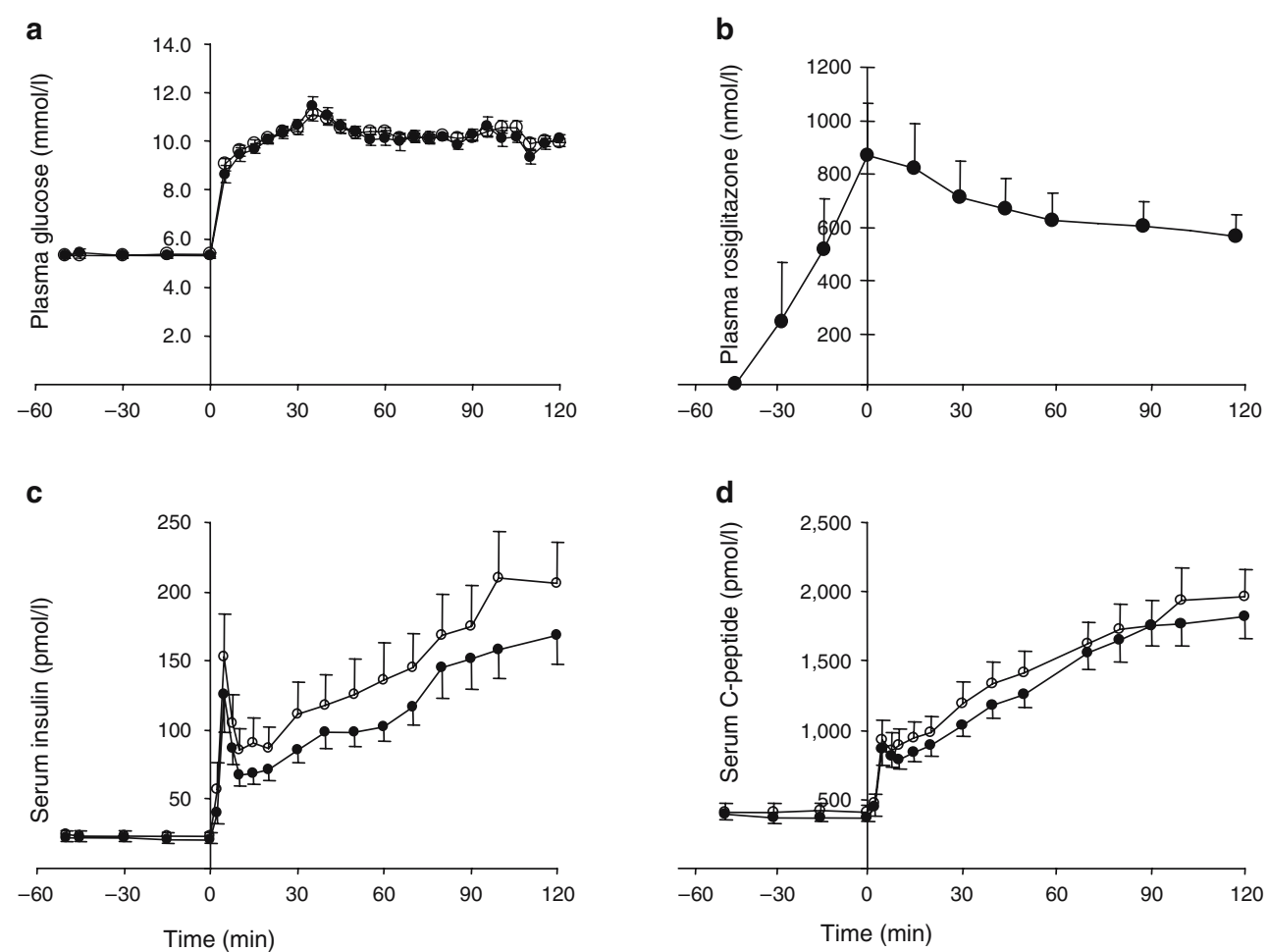

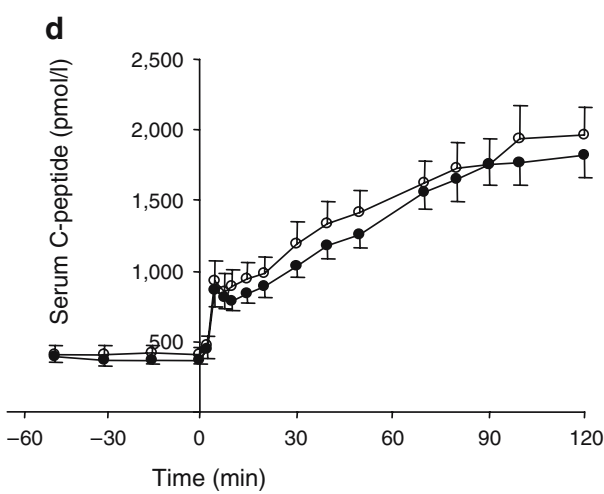

decreased and plateaued at about $600 \mathrm{nmol} / \mathrm{l}(300 \mu \mathrm{g} / \mathrm{l})$ from 45 min onwards (Fig. 1b).

Figure $1 \mathrm{c}$ and $\mathrm{d}$ displays the glucose-induced modifications of insulin and C-peptide concentrations. Rosiglitazone did not modify baseline hormone concentrations (insulin: $21.0 \pm 2.1 \mathrm{vs}$ $23.4 \pm 2.6 \mathrm{pmol} / \mathrm{l}$, NS; C-peptide: $369 \pm 36$ vs $408 \pm 56 \mathrm{pmol} / \mathrm{l}$, NS). Regarding the insulin response, there was no treatment effect on the first phase $\left(\mathrm{AUC}_{\text {insulin } 0-10}: 742 \pm 121\right.$ vs $924 \pm$ $\left.181 \mathrm{pmol} \mathrm{l}^{-1} 10 \mathrm{~min}, \mathrm{NS}\right)$, whereas the second phase was significantly decreased in the presence of rosiglitazone $\left(\mathrm{AUC}_{\text {insulin }} 10-120: 13,066 \pm 1,531\right.$ vs $16,316 \pm 2,813 \mathrm{pmol} \mathrm{l}^{-1}$ $110 \mathrm{~min}, p<0.05$ ). In contrast, serum C-peptide concentrations remained similar between rosiglitazone and placebo sessions, during both the first phase $\left(\mathrm{AUC}_{\mathrm{C} \text {-peptide } 0-10}: 6,699 \pm 675\right.$ vs $7,285 \pm 989$ pmol $1^{-1} 10 \mathrm{~min}$, NS) and the second phase (AUC $_{\mathrm{C} \text {-peptide } 10-120}: 155,018 \pm 12,691$ vs $167,962 \pm$ $17,939 \mathrm{pmol}^{-1} 110 \mathrm{~min}$, NS). Accordingly, the insulin clearance was significantly higher after rosiglitazone intake as compared with placebo (Table 1).

The insulin sensitivity index was significantly increased by rosiglitazone (Table 1). The change in insulin sensitivity index (difference between the rosiglitazone and placebo sessions) correlated neither with the changes in insulin AUC $(r=0.196, p=\mathrm{NS})$ nor with the change in insulin clearance $(r=-0.154, p=\mathrm{NS})$.

No carry-over effect was observed.

\section{Discussion}

In this study, we report for the first time acute effects of a thiazolidinedione on both insulin sensitivity and insulin clearance indexes in human subjects after a single oral dose.
Table 1 Comparison of glucose and insulin parameters between the rosiglitazone and placebo sessions: means $\pm \mathrm{SE}$

${ }^{*} p<0.05,{ }^{*} p<0.01$ (rosiglitazone session vs placebo session)

\begin{tabular}{lcc}
\hline & Session & \\
\cline { 2 - 3 } & Placebo & Rosiglitazone \\
\hline Mean plasma insulin & & $147.8 \pm 19.3$ \\
Glucose infusion rate $(\mathrm{pmol} / \mathrm{l})$ & $180.7 \pm 29.2$ & $1,553 \pm 166$ \\
Insulin sensitivity index $\left(\mu \mathrm{mol} \mathrm{m} \mathrm{m}^{-2} \mathrm{~min}^{-1} \mathrm{pmol}^{-1} 1\right)$ & $1,328 \pm 159$ & $12.0 \pm 1.5^{* *}$ \\
Insulin clearance (molar ratio of C-peptide to insulin AUCs) & $8.5 \pm 1.1$ & \\
$0-10$ min & & $10.02 \pm 0.87^{*}$ \\
$10-120$ min & $11.55 \pm 1.37$ & $13.01 \pm 1.40^{*}$ \\
$0-120$ min & $11.38 \pm 1.33$ & $12.80 \pm 1.34^{*}$ \\
\hline
\end{tabular}


The hyperglycaemic clamp technique is considered the gold standard to evaluate beta cell function, and provides an accurate estimation of insulin sensitivity [6]. Our experimental conditions for glycaemia and rosiglitazone concentrations were appropriate. One limitation of our methodology is the estimation of insulin clearance by the ratio $\mathrm{AUC}_{\mathrm{C} \text {-peptide: }}$ : $\mathrm{AUC}_{\text {insulin }}$ instead of deriving insulin secretion rates by deconvolution of C-peptide concentrations. We preferred this method because given the high individual variability in C-peptide kinetics [7], using fixed standard kinetic parameters in a small sample may be erroneous.

Both animal studies and long-term human studies in type 2 diabetes suggest beneficial effects of thiazolidinediones on pancreatic beta cells, but it remains unclear whether it is a direct effect or secondary to modifications in insulin sensitivity and glucotoxicity. In our acute model, the reduction in insulin concentrations associated with a conserved C-peptide response, suggests an immediate increase in insulin clearance, consistent with the long-term increase previously described [3]. In this latter study, the authors proposed that the rosiglitazone-associated rise in insulin clearance could be secondary to a decreased liver fat content [3]. Here we suggest another mechanism, as the immediate increase of insulin clearance following rosiglitazone intake makes it unlikely to be accounted for by a modification in fat content. Moreover, as the change in insulin clearance is not correlated with the change in the insulin sensitivity index, it is more likely to be a direct effect of rosiglitazone rather than a consequence of the change in insulin sensitivity.

The insulin sensitivity index was immediately increased after acute rosiglitazone intake. One limitation of our methodology is that clamp studies cannot differentiate between an authentic effect on insulin sensitivity or an insulinomimetic effect. Our results challenge the contention that thiazolidinediones act via PPAR- $\gamma$-dependent gene expression only, as the rapid onset of the insulin-sensitising action is not compatible with a modulation of gene transcription [8]. Alternatively, a rapid-onset insulinindependent stimulation of glucose uptake was also demonstrated after thiazolidinedione administration in several cell lines. Other explorations are needed to better examine glucose utilisation after acute rosiglitazone administration.

In conclusion, we demonstrated an acute effect of a single dose of rosiglitazone on insulin clearance and insulin sensitivity index in healthy volunteers, suggesting new aspects of thiazolidinedione action in humans. The therapeutic implications of these findings remain to be evaluated.

Acknowledgements The expert technical assistance of F. Costa, I. Gabillaud and A. Massebiau (research nurses) is gratefully acknowledged. We thank A. Bonardet, B. Bories-Azeau, A. Cadène, J. Foppolo, P. Rambourg and A.-M. Puech-Cathala for their contribution. We also thank S. L. Salli for presubmission editorial assistance. This study was sponsored and financed by the Montpellier University Hospital and received an additional grant from GlaxoSmithKline Laboratory (Marly-le-Roi, France).

Duality of interest None of the authors has a conflict of interest regarding the content of this paper.

\section{References}

1. Lehman JM, Moore LB, Smith-Oliver TA, Wilkinson WO, Willson TM, Kliewer SA (1995) An antidiabetic thiazolidinedione is a high affinity ligand for peroxisome proliferator-activated receptor gamma (PPAR gamma). J Biol Chem 270:12953-12956

2. Kim SH, Abbasi F, Chu JW et al (2005) Rosiglitazone reduces glucose-stimulated insulin secretion rate and increases insulin clearance in nondiabetic, insulin-resistant individuals. Diabetes $54: 2447-2452$

3. Tiikkainen M, Hakkinen A-M, Korsheninnikova E, Nyman T, Makimattila S, Yki-Jarvinen H (2004) Effects of rosiglitazone and metformin on liver fat content, hepatic insulin resistance, insulin clearance, and gene expression in adipose tissue in patients with type 2 diabetes. Diabetes 53:2169-2176

4. DeFronzo RA, Tobin JD, Andres R (1979) Glucose clamp technique: a method for quantifying insulin secretion and resistance. Am J Physiol 237:E214-E223

5. Polonsky KS, Given BD, Hirsch L et al (1988) Quantitative study of insulin secretion and clearance in normal and obese subjects. J Clin Invest 81:435-441

6. Mitrakou A, Vuorinen-Markkola H, Raptis G et al (1992) Simultaneous assessment of insulin secretion and insulin sensitivity using a hyperglycemia clamp. J Clin Endocrinol Metab 75:379-382

7. Polonsky KS, Licinio-Paixao J, Given BD et al (1986) Use of biosynthetic human C-peptide in the measurement of insulin secretion rates in normal volunteers and type I diabetic patients. J Clin Invest 77:98-105

8. Brunmair B, Gras F, Neschen S et al (2001) Direct thiazolidinedione action on isolated rat skeletal muscle fuel handling is independent of peroxisome proliferator-activated receptor-gamma-mediated changes in gene expression. Diabetes 50:23092315 